\title{
'Choreographic performance, generations and the art of life in post-colonial Dakar
}

\author{
Hélène Neveu Kringelbach \\ African Studies Centre, University of Oxford
}

September 2013

\begin{abstract}
Hélène Neveu Kringelbach is an anthropologist, and currently a researcher with the Leverhulme-funded Oxford Diaspora Programme, based at the African Studies Centre. Her current research looks at transnational families across Senegal, France and the UK. She was previously a lecturer in Anthropology and African Studies, also at Oxford (2006-2011). She has carried out extensive research on choreographic performance in Senegal, and her monograph on the subject is in press with Berghahn Books.
\end{abstract}

\begin{abstract}
This article looks at three generations of choreographic performers in urban Senegal to examine the creative ways in which people develop their bodily skills, not only for the pleasure of innovation, but also to 'make their way into the world'. In so doing, they produce new social spaces, and engage with a multiplicity of existing ones. I suggest that this multiple engagement characterizes contemporary urban Africa, where social mobility is conceived of as multiplying the possibilities of building a decent life in spite of economic hardship. In West Africa, this is in continuity with a long history of social mobility achieved through travel and the acquisition of new skills. Through a multiple engagement with different genres, performers also experiment with new ways of producing choreographic work. At every juncture, the social spaces thus produced alternatively intensify and reduces the connections with global spaces already laid out by previous generations.
\end{abstract}


When I first got to know the Dakarois dance world in 2002, the boundaries between generations of artists seemed to be clear-cut. There were the 'elders', who had started performing in the 1960s or 70s. By then they had either retired or still held leading positions as choreographers, 'ballet masters', troupe leaders, or theatre directors. Then there was the next generation, many of whom had been struggling to build up artistic careers for years, and felt that the previous generation had 'not prepared the ground' for them to take over. Coming after them was another generation who aspired to perform on stages worldwide, and came across as more confident in their artistic abilities. But they, too, complained about being hampered by their 'elders'. Over time, I realized that despite the frustration that was being expressed, there were strong bonds of apprenticeship and kinship (real or fictive) between these generations. Everybody seemed related one way or the other. This was visible in the continuities in performing styles of course, but also in the shared cosmopolitan aspirations of individuals, and in shared concerns with maintaining a balance between individual success and a socially valued morality. This was in stark contrast with a widespread discourse according to which radical change had taken place in the 1980s and 1990s. There were also 'horizontal' connections across genres as the same people engaged with multiple genres, from popular dances in ceremonies and festive events to neotraditional troupes and contemporary choreography.

In this article, I follow individual trajectories over three generations to examine the creative ways in which performing artists in urban Senegal develop their bodily skills, not only for the pleasure of innovation, but also to 'make their way into the world'. In so doing, they produce new social spaces, and engage with a multiplicity of existing ones. Following Simone (1998), I suggest that this multiple engagement characterizes contemporary urban Africa, where social mobility is conceived of as multiplying the possibilities of building a decent life in spite of economic hardship. In West Africa, this is in continuity with a long history of social mobility achieved through travel and the acquisition of new skills. Through the process of multiple engagement, performers also experiment with new ways of producing choreographic work. Importantly for the theme introduced by Castryck and Sieveking in this issue, at every juncture the social spaces thus produced alternatively intensify and reduces the connections with global spaces already laid out by previous generations. 
The focus here is on dancer-choreographers, recent figures who have emerged alongside 'contemporary dance' in West Africa, a mode of choreographic production which places creative agency firmly with the individual performer. I often use the term 'performer' rather than 'dancer' or 'dancer-choreographer' to avoid drawing too neat boundaries between integrated elements of performance. I take to heart Drewal's (1991) and Gore's (2001) important discussions, who argue that the notion of music, dance and drama as distinct elements is Eurocentric, and the outcome of fairly recent disciplinary boundaries. As Drewal (1991: 16 ) says, 'while performers often specialize in certain performance genres drumming, dancing, singing - these activities rarely happen in isolation'. Indeed in Dakar, many dance troupe members are able to dance, play the drums, sing and act, but there is also a strong awareness of individual skills.

This contribution forms part of on-going research on performance in Senegal, and with Senegalese performers in various other locations (France, the UK, South Africa). The research draws on approximately 18 months of fieldwork between 2002 and 2012. Here I should introduce a caveat: although the broader research this forms part of includes a wide range of performers and genres, I have purposefully focused on individuals who engage with several genres. This is because they exemplify the strategies deployed by many city dwellers in Africa. I have thus left out those performers who remain within a single genre, often neotraditional performance or popular dances for music videos and TV competitions. ${ }^{1}$

\section{Transforming social space through performance}

The rich literature on popular culture and expressive genres in Africa that has emerged since the mid-1990s illuminates some of the ways in which the resonance of performing genres with real life, and the pleasure generated by their aesthetic qualities, create new social spaces by bringing people together in new ways as 'makers' and audiences.

Karin Barber's (2000) brilliant study of the Adéjọbí Company, a Yorùbá travelling theatre troupe she worked with in the 1980s, is an instance of this. Barber describes in exquisite detail a genre of popular theatre which drew on older modes of performance in Yorùbáland to project new ideas of morality, autonomy and individual success in post-colonial Nigeria. In doing so, Yorùbá travelling theatre carved up a new public arena, made up of socially

\footnotetext{
${ }^{1}$ I explore these genres in more detail elsewhere (Neveu Kringelbach 2013).
} 
diverse audiences. These audiences took to the theatre because they enjoyed the entertainment of course, but also because the plays provided a space within which these ideas could be reflected upon. There was a dialectical relationship between life and theatre, and between personhood and performance. Thanks to the time-depth in her study, Barber was able to show how these notions had changed over time, and how they had become inflected differently in the company's work over the years. I draw on Barber's insights here to suggest that the practice of choreographic performance in Dakar contributes to the production of an urban, cosmopolitan social space which involves new ideas about the person. I have limited the scope to the post-colonial period because Independence in 1960 marked a time when theatrical production benefited from major investment from the Senegalese state. In many ways however, this is an arbitrary beginning since there were dance troupes after World War II already. But a more detailed exploration of the history of theatrical dance in Senegal is underway elsewhere (Neveu Kringelbach 2013).

For many youths in contemporary urban Senegal, 'making it' into the world beyond the city involves the acquisition of new bodily techniques as well as the mastery of new technologies of communication (Neveu Kringelbach 2013). One must be careful, however, not to portray aspirations to an intensified engagement with the wider world as an entirely new phenomenon. Indeed the salient difference in the Senegalese performing world is not so much between 'before' and 'after' a colonialism-induced modernity as it is between those generations who had access to state patronage and those who did not. The transformations this article focuses on could thus be summarized as follows: the generation of artists which became active in the immediate post-independence benefited from the support of the state to an exceptional degree, and they were able to promote their own creative agency without depending on older modes of apprenticeship. The generation who came after looked forward to the same opportunities, but these dried up, and they eventually had to look outside Senegal for funding and training. Many left the country altogether, and those who stayed turned back to 'tradition' for inspiration. The third generation never expected the state to look after them, and knew from the start that individual success would have to come from increased engagement with global artistic circuits; therefore they would have to acquire the techniques to achieve this.

This relates to the continuous production and reproduction of social space as conceived by Lefebvre (1974), and further elaborated by geographers and scholars of urban contexts. 
This vein of scholarships seeks to break with earlier European notions of space as being simply 'place' inhabited and given meaning to, and to reflect on the ways in which historical processes and relations of power (the advent of capitalism in Lefebvre's work) shape the physical urban environment as well as the networks and social relations that develop over time. As Castryck and Sieveking point out in their contribution, drawing also on Massey's work, social space is thus produced by a 'cross-cutting, intersecting, aligning' of networks of interaction and opposition over time (Massey 1994: 3), and history can be 'imagined as the product of layer upon layer of different sets of linkages, both local and to the wider world' (Massey 1991: 29). This contribution will then examine the specific ways in which choreographic performance, as well as the movement of performers over space and time, form part of and shape these layers of history. I suggest here that performance does not simply reflect what happens in society, but actively shapes it, too.

\section{Life aspirations and mobility within and out of Africa}

An important point which follows on from the role of performance in the production of social space is that looking at the trajectories of performers over time enables us to get at the texture of the space thus created. As Simone (1998) pointed out in relation to urban Africa more generally, it has become vital for youths to develop the capacity to move between social spheres, not only within the region but also outside the continent. The burgeoning literature on youth and ways of coping with uncertainty in Africa has gone a long way in demonstrating the enduring propensity of African youths to move between social spheres at a local and regional level (Abbink and Van Kessel 2005 ; Christiansen, Utas, and Vigh 2006 ; Honwana and De Boeck 2005 ; Vigh 2006 ; Weiss 2009), but the simultaneous engagement with social spheres outside the continent is relatively underplayed in many of these studies.

Mobility between social spheres at the regional level has long been an essential dimension in the lives of specialized performers in the Senegambian region. In Wolofspeaking Senegal for example, oratory praise performance, singing, music-making and dancing for a reward, has long been associated with the hereditary status of griots (géwël) 
and other categories of artisans. ${ }^{2}$ Public performance involving music and dancing was thus conceived of (and to a certain extent still is) as a ritualized service provided by highly skilled, specialized dependents to validate or enhance the status of their patrons. For talented individuals from géwël or other ñeeño families, acquiring the necessary skills to become a valued performer, or developing new ones so as to innovate, used to involve travelling widely across the region (Hale 1999). But in Senegal as elsewhere in Francophone West Africa, the performing profession was transformed by the introduction of modern theatre (with a strong musical and choreographic component) into colonial schooling by the French authorities from the 1930s onwards. There is no space to chart this history in detail here, but the important point is that Senegal's early cultural policies in the post-colonial period, under Léopold Sédar Senghor's presidency, built further on this colonial history, while also drawing on the older patterns of mobility established within griots families. As we will see through the generational trajectories presented below then, the current engagement of performers with social spheres outside the continent should be understood as an extension of these earlier 'layers' of mobility.

Yet as I have suggested, the literature on youth and life aspirations in urban Africa rarely intersects with that on transnational migration, and this is in part because these strands come out of different scholarly traditions. There is a voluminous body of work on the migration strategies of young Africans, but much remains to be said on the ways in which people from the continent aspire to travelling lifestyles rather than 'migration' as an endpoint. A rich literature is emerging, which focuses on the tightening of immigration policies in northern countries, and the effects of forced 'immobility' on societies where travelling had become a favoured path towards social adulthood (e.g. Carling 2002 ; Jonsson 2011). This approach is productive because it takes into account the social value placed on spatial mobility: though leaving Africa has become more difficult and costlier, aspirations to mobile lifestyles and the desire of senior family members to have 'children abroad' continue to inform how people shape their urban life-world.

\footnotetext{
2 The term ñeeño is employed to designate the broader group which includes griots as well as blacksmiths, jewellers, leatherworkers etc. In other words, they include the trades which have historically required specific skills to 'transform' matter into something of value in social relations. Griots, or 'praise-singers' are they are often referred to in the literature, are no different since they transform oratory arts, music and choreographic performance into social status on behalf of others. There has been extensive scholarly debate on the extent to which this form of caste-like stratification was inherently hierarchical, or rather based on the complementarity of different forms of power (cf. Diop 1981 ; Irvine 1989 ; Wright 1989 ; Tamari 1997).
} 
I now turn to the three generations of performers who are the core producers of the urban and globally connected social spaces this article explores. In using the term 'generation', I have remained faithful to the way in which performers themselves describe their position in relation to each other. In Dakar as elsewhere on the continent, youth and seniority are relational categories, not absolute ones (Durham 2000). Age is certainly important to dancers because this is what eventually puts a limit on their vitality, and thus at times dancers appear particularly rushed in their desire to 'make it'. ${ }^{3}$ But seniority is also determined by the duration, intensity and quality of one's experience in the performing world.

\section{The first generation: the 'cosmopolitan nationalists'}

The performers who belong to the 'first generation' became active in the 1960s and 1970s, in the hopeful days of the post-Independence period. Under Léopold Sédar Senghor's presidency, Senegal invested heavily in the patronage of 'culture and the arts' (Snipe 1998 ; Harney 2004). These were, as many artists remember with nostalgia, Senegal's golden years for the arts, and those who came of age during this period benefited from unique opportunities. A number of them were able to receive solid artistic training in Senegal and abroad and went on to lead cosmopolitan lives, sometimes without much formal education to begin with. This was, therefore, the generation with whom the social status of performers began to shift. Many among this generation discovered a passion for dance through evening dances with Cuban music, which were extremely popular in the cities of coastal Senegal at the time. The popularity of Cuban music in coastal West Africa was itself the product of colonial trade routes between Africa, Europe and the Caribbean (White 2002) as well as the return of West African soldiers at the end of World War II (Benga 2002). This generation's initial engagement with dance, therefore, came through the transnational space created by the violent reorientation of Senegal toward the Atlantic world.

Dance veteran Ousmane Noël Cissé, for example, did not come from a géwël background. His mother was a Lebu from Dakar, and his father a Muslim cleric from Niger. Born in Dakar in 1945, he was young in the 1960s when Cuban music was all the rage, and

\footnotetext{
${ }^{3}$ See Wulff (1998) for an excellent discussion of ageing in the classical ballet world.
} 
when the stars of the urban dance floors were often Cape Verdeans settled in Senegal. In the late colonial period, the most significant artistic event had been the West African tour of a Paris-based troupe, Guinean Fodéba Keita's Ballets Africains. Dakar was the capital of French West Africa, and the troupe's success in Paris had compelled the Governor to invite them on a regional tour. They performed in Dakar in 1956-57, to the delight of future President Senghor. When they returned in 1961, several performers stayed behind to set up their own troupes. This was a time of experimentation, and to promote the emerging genre of neo-traditional performance which came in the wake of the Ballets Africains, President Senghor set up the National Ballet in 1961. The troupe drew on the work of Keita's troupe of course, but also on the youth theatre groups which had flourished throughout the region since the early 1950s under the impulse of schoolteachers and other educated youths. Among the Ballets Africains' former performers who stayed in Dakar was Guinean Lamine Conté and his Ballets d'Afrique Noire, where drummer Mansour Guèye made his début. Guèye later created his own troupe and became a pillar of the Senegalese performing scene for more than three decades (Castaldi 2006). There was an effervescence of dance troupes drawing on innovative combinations of regional dances and European theatre techniques. But there was no institutional training in Senegambian dances, and Dakar's dance schools at the time mainly taught classical ballet to European and middle-class African children. The new dance troupes therefore recruited two categories of performers: rural migrants, and urban youths who had shown a style of their own on the Cuban-inflected dance floors.

Around 1960, Cissé was recruited into Conté's Ballets d'Afrique Noire. Within a few years he was dancing with several troupes simultaneously, hiding his dancing from his family. Most likely, they knew about it but did not object so long as it was not too obvious. His passion was nourished by the desire to follow into the footsteps of Keita's troupe: 'We all admired the Ballets Africains', he told me when I interviewed him in Dakar in 2011; 'to travel around the world like they did, that was our dream!' A turning point in Cissé's trajectory came with his recruitment into the National Ballet, early in the year of Senegal's most ambitious event in Senghor's presidency: the 1966 World Festival of Negro Arts. Ahead of this magnificent tribute to his own power, Senghor had wanted to professionalize the National Ballet, and had invited African American choreographer Katharine Dunham to help with the task. It was Dunham who had chosen Cissé after seeing his Cuban-style improvisations. 
During the World Festival, Cissé saw the Alvin Ailey Dance Company perform its flagship piece 'Revelations' in the brand new Daniel Sorano National Theatre. He described watching the piece as a life-changing experience. From then on, he was not going to confine himself to neo-traditional performance. Cissé joined forces with Dunham's assistant Oliver Johnson, and eventually set up the very modern Afro-American Dance Company. Meanwhile he continued to work with the National Ballet, whose original troupe, La Linguère, focused on jembe rhythms from the wider Mande area. The shows were mainly made up of theatrical tableaux of rural life, inspired by the creations of the Ballets Africains in Paris in the 1950s and re-imagined by National Theatre director Maurice Sonar Senghor, the President's nephew. Sonar Senghor had indeed developed a passion for theatre during his student days in Paris, where he had befriended Fodéba Keita and other students and artists from Africa and the Diaspora.

Around 1975, Senghor decided to create a second troupe within the National Theatre: Sirabadral, named after a $14^{\text {th }}$-century Sereer princess from Senghor's region of birth. That way, La Linguère and Sirabadral could specialize in different styles. Since the first troupe toured extensively in its mission as Senegal's 'cultural ambassador', home audiences were somewhat neglected; Sirabadral would travel too, but its main focus would be the domestic dimension of nation-building. Cissé was appointed director of the new troupe, which introduced Sereer and Wolof rhythms as well as 'modern dance'. The troupe's syncretic approach was shaped by Senghor's version of Negritude, and the President encouraged artists to 'rediscover' the region's dances and rhythms and codify them before integrating elements from other cultures. Cissé experimented with blending regional rhythms and movements styles with classical ballet and American modern dance, and coined a Wolof term for his style: repede.

Generous state funding enabled Cissé to plug himself into artistic networks outside Senegal. A further turning point in his trajectory came when he met French choreographer Maurice Béjart, a major figure in $20^{\text {th }}$-century neo-classical dance. Béjart had a long-standing interest in Senegal since his father, philosopher Gaston Berger, was born in a Creole family in Saint-Louis. In 1975, he invited Sirabadral to perform in Brussels alongside his own 
company, Le Ballet du $20^{e}$ Siècle. Cissé was subsequently invited to pursue dance training at Béjart's prestigious Mudra dance school in Brussels. ${ }^{4}$

Upon return to Senegal in the early 1980s, Cissé launched the Manhattan Dance School, which taught classical ballet, American-style jazz and modern dance. By then, American pop music was replacing Cuban styles as the favourite music of the youth. Upper-class Senegalese and European youths flocked to the school, eager to learn how to move 'the American way'. And since European classical ballet was taught as well, the training was acceptable to well-off Senegalese parents who saw ballet classes for their children as a mark of distinction. In the mid-1980s, a further opportunity presented itself: promoting the designs of the state-owned textile company, Sotiba. Cissé put together a group of boys and young men, the Sotiba Boys, and moved his studio to the factory site on the edge of Dakar. Under the impulse of Sotiba's Marketing Director, the group achieved tremendous success by dancing at corporate events and on TV programmes, wearing Sotiba's designs and performing Cissé's choreographies. The adventure only lasted for a few years however, and Cissé went back to teaching. After a successful career in Cape Verde in the second half of the 1990s, he returned to Senegal in the mid-2000s.

Engaging with various choreographic genres over time undoubtedly provided Cissé with artistic and life opportunities he would not have had if he had confined himself to one genre. Significantly, it was state patronage that made it possible for him to achieve success abroad as well as recognition at home. For this generation, there was little space to operate outside state control, as the trajectory of dancer-choreographer Mamadou Diop, below, also demonstrates. But this multiple engagement also gave Cissé moral authority as someone who had brought innovation and international visibility to the Senegalese choreographic world. When I met him, he made a point of telling me about all the dancers from the next generation whom he had trained at some point. Much of his narrative was thus about tracing connections back to himself.

In the 1960s, another performer of the same generation, Mamadou Diop, enrolled at the National School of Arts to be trained as an actor. A French lady, Mrs Boblin, was teaching classical ballet there. Upon hearing the piano, Diop walked in on one of her classes.

\footnotetext{
${ }^{4}$ Léopold Sédar Senghor and Maurice Béjart established a Pan-African branch of the Mudra school in Dakar in 1977: Mudra Afrique. The school closed in 1983, but a number of its students went on to successful international careers. Germaine Acogny, a Senegalese dancer and choreographer originally from Benin, was appointed director of the school from its opening.
} 
Initially intrigued by a style he could barely identify as dance, he soon became passionate about ballet. Mrs Boblin asked for him to be transferred to the dance section, from where he simultaneously pursued acting. By the early 1970s, however, the National Theatre could no longer absorb entire cohorts of graduates from the School of Arts. Diop and a few of his peers founded the first private theatre troupe in independent Senegal, the Tréteaux Sénégalais. ${ }^{5}$ Like Cissé, Diop used the language of experimentation to explain how he had wanted to create new ways of incorporating dance into theatre as a narrative element in its own right, with a view to creating 'a new aesthetics of dance in modern Senegalese theatre'. ${ }^{6}$ The troupe struck a chord with the Ministry of Culture when they staged Chaka, President Senghor's play on the legendary Zulu king. Senghor gave a generous donation, which enabled the creation of two further plays. One of these, Le Train de la Liberté, paid homage to Nelson Mandela and the fight against apartheid. It did not find favour with the President regime however, most likely because the play portrayed a struggle against a government in place. Chaka, by contrast, had been an anti-colonial epic very much in line with the themes favoured by the National Theatre at the time. Though the troupe survived for another ten years, state funding was no longer forthcoming.

By the early 1980s, Abdou Diouf had replaced Senghor as President. State patronage of the arts was dramatically cut in the face of economic decline, but Senegal had retained a bilateral agreement of cultural exchange with the Soviet Union. Diop left the ailing theatre and made his way to Moscow, where he spent five years studying choreography at the State Institute of Theatre Arts. He went on to win the second prize at a choreography competition in Moscow, and was then commissioned to create modern musical plays for several Soviet theatres. By the time he returned home a few years later, he was eager to have another chance at the world of state-sponsored 'culture'. It was therefore a huge disappointment when his application to the National Theatre was turned down. He also knew from his experience with independent theatre that private initiatives were risky affairs, and chose to become a teacher at the National School of Arts, where he later became Head of the Performing Arts section. Despite this success, Diop never quite achieved the recognition he had longed for. His family had always been opposed to his dancing career, and had agreed

\footnotetext{
5 Tréteau means 'wooden plank' in French. The troupe's name was chosen to express the experimental, but also the skilled trade-like nature of its work.

${ }^{6}$ Personal communication, Dakar, April 2003.
} 
to let him travel to Russia on the condition that he 'pulled himself together and did something proper' with his life. That he was now in a leadership position in a state-owned institution had not fundamentally altered their position.

Driven by a passion for dance and a desire for novelty, both Cissé's and Diop's lives were heavily shaped by the acquisition of new performing techniques, both at home and abroad. They had the opportunity to do so because they saw the value of novelty and worked hard to master new genres, of course, but also because they were able to activate and develop long-established connections between Dakar and the wider Senegambian region, and between Dakar and the wider world. It did matter that they lived in a city which attracted artists and intellectuals from all over the world at the time, a phenomenon itself rooted in Dakar's former status as the capital of colonial French West Africa, and a particularly cosmopolitan place from World War II onwards. Cissé's training in Brussels was thus made possible by a pre-existing connection between choreographer Maurice Béjart and colonial Senegal, via Dakar and the coastal city of Saint-Louis. But this connection was also activated and developed further because under Senghor's leadership, the Senegalese state regarded it as its best interest to intensify its networks of artists and intellectuals throughout the world (especially in Europe and North America).

The state patronage (and control) of the 1960s and 1970s enabled this generation of artists, the successful ones among them at least, to establish positions of power in state institutions, move on to international careers, and back again. Though some performers from that generation stayed abroad, many more returned and tried their best to fit in within a soon declining state apparatus. The transition to the difficult years of the Structural Adjustment Programmes (SAPs) generated a strong nostalgia for the Senghorian years, when artists were the regime's 'darlings' (Harney 1996). Travels were meant to provide additional resources (in terms of skills, networks and money) to create a modern Senegalese society. Flights were expensive but visas were either unnecessary or fairly easy to obtain, and there was a sense of a cosmopolitan life. Disappointment was therefore bitter for those who did not achieve success. A number of performing artists from this 'first' generation left Senegal again in the 1980s, and either established themselves abroad for good or returned much later. Several authors working on intergenerational relations have suggested that people position themselves differently in relation to other generations, depending on the stage of life at which they are speaking. Speaking in the 2000s, this generation of 
'cosmopolitan nationalists' are often left with a longing for the days when they believed they were going to lead the country 'forward'. They often hang on to narratives tracing the success of subsequent generations and state institutions back to them, but little is ever said of those who came before them. Yet the cosmopolitan social space they helped to expand certainly built on previous, enduring 'layers' of Atlantic connections and regional travel for the purposes of apprenticeship.

\section{The second generation: the 'state's orphans"}

The 'second' generation, whom I call the 'state's orphans', came to artistic maturity in the 1980 s and the first half of the 1990s, during a period of minimal state funding for the arts. Although this made space for other projects aside from nation-building, resentment sometimes arose as this generation found itself 'stuck' underneath the previous one. They found that they had to wait longer than expected for their turn to dance, and unfortunately, this happened at a time when immigration policies in Europe made it increasingly difficult for them to travel. Caught between a previous generation still in place and declining opportunities for innovation within the state-funded arts world, those who did not simply stay behind during international tours turned inwards and attempted to re-discover the 'traditions' which they felt their senior peers had neglected. This resonates with recent work on intergenerational relations in Africa, much of which now foregrounds the role of performance and popular culture in articulating intergenerational tensions. Reynolds Whyte et al. (2008: 11) thus see the resurgence of an interest in 'tradition' as the outcome of the uncertainty of the contemporary period, which pushes the younger generation to take up 'the banner of tradition in the name of a past that they idealize as a way out of present difficulties to a better future'. Closer to Senegal, in Côte d'Ivoire, Schumann (2012) also speaks of a 'generation of orphans' to characterize the sense of abandonment felt by the Ivorian youth who came of age during the economic crisis of the 1980s. This frustration eventually led to violence, with the Ivorian crisis of 2002-07, and was expressed in such forms of popular culture as Zouglou music.

\footnotetext{
${ }^{7}$ In naming this generation I have drawn inspiration from Harney's (1996) metaphorical description of visual artists in 1990s-Senegal as the 'dear children without their father', in reference to Senghor stepping down as President in 1980 and to the shrinking of state patronage.
} 
One of the most experienced dancer-choreographers of this generation, Jean Tamba, was born in Dakar in the 1960s from parents who were migrants from Casamance. Like his father before him, he always had a passion for dancing, and as a young man he loved clubbing. In the early 1980s, Tamba was recruited into a neo-traditional troupe led by master drummer Ahmed Kunta. There, Alioune Fall, a former dancer with Mansour Guèye, taught him dances and rhythms from across the region. Like many of his peers, Tamba insisted that he had learned 'proper traditional rhythms', rather than the modernized and simplified versions he believes younger performers get away with today. Tamba describes the 1980s as a time of intense competition in neo-traditional troupes ('ballets'), where young performers had to wait for years for their turn to perform proper roles. But in those days it was worth waiting, Tamba said, because performing in Dakar's big hotels paid generously. He would often go and watch the Mudra Afrique students in the school's grand building on the seafront. It was there that he discovered modern dance styles he had never seen before, and this made a deep impression on him.

Having risen from the status of apprentice to that of fully-fledged performer in Maitre Kunta's troupe, Tamba made his début as a choreographer, and this gave him confidence in his ability to try out new genres. By the late 1980s, he joined Cissé's Sotiba Boys while also performing with the neo-traditional troupe. Tamba always beamed with pleasure at the memory of the TV shows, the trips to other Senegalese cities, and the cohorts of admiring girls. Now determined to open up new artistic paths for himself, he took classical ballet classes with Andrée Lorenzetti, a former dancer with the Ballet de Marseille who had opened a studio in Dakar. In 1989 he enrolled at the National School of Arts for a six-year performing arts curriculum, which included classical ballet and drama. Meanwhile he also danced at Cissé's Manhattan Dance School and took part in workshops with visiting dancers like African American choreographer Chuck Davis, who had come to perform with his African American Dance Ensemble.

Upon graduation in 1995, Tamba and youth organizer Honoré Mendy set up a contemporary dance company, La $5^{e}$ Dimension. Like Cissé and Diop before them, they wanted to create a free space in which to experiment with mixing regional rhythms with moves from Euro-American choreographic genres. Senghor's ideas on cultural creolization resonated with their own, and this was reflected in the name they coined for the company's style: 'metiss dance'. They were reproducing what Cissé, one of Tamba's early mentors, had 
tried to do before: to create a syncretic style by naming it. Indeed this generation wanted to create both for international publics and for an increasingly outward-looking home audience.

Dancers and drummers were recruited among young performers encountered during the Manhattan Dance School days, like brothers Landing and Ousmane Mané, or among peers from the National School of Arts. The company really came together when the performers were invited to take part in the first professional workshop held in 1998 at Germaine Acogny's newly opened choreographic centre in Tubaab Jallaw, a Lebu fishing village on the coast south of Dakar. The Ecole des Sables, as it was nicknamed in reference to the sandy texture of its open-air dance floors, was established that year to work along the same Pan-African principles on which the short-lived Mudra Afrique had been founded in the late 1970s. By contrast with Mudra Afrique however, funding was not going to come from African states but from French and European agencies, private charities in Europe and North America, and from fee-paying students from outside Africa. The workshop was a turning point for most of the participants because it gave them the opportunity to work with internationally renowned artists, and to experiment with individualized choreography in professional conditions. This led to a contemporary piece by German choreographer Suzanne Linke, Le Coq est Mort, which featured eight male dancers. Though Linke had final agency in selecting the movement sequences and the spatial arrangement, the piece was a joint creation involving every participant. The show toured over two years across Europe and North America, featuring at such prestigious venues as the Jacob's Pillow Festival in Massachusetts in 2000.

Following Le Coq est Mort, Tamba's company recruited new performers who now shared a common approach to choreographic work. The $5^{e}$ Dimension Company produced several full-length pieces, and was eventually invited to perform at the prestigious contemporary dance 'Biennale' in Lyon in September 2006. Aspirations to a transnational career seemed to materialize for the group, which appeared as a closed-knit 'family' during those years, despite the departure of several dancers who had left in the late 1990s to work with international productions, set up their own group or establish themselves as 'freelance' performers. One of the women dancers, Simone Gomis, had also taken part in a contemporary dance workshop in Montpellier, and in 2001 she was recruited by FrenchAlgerian choreographer Heddy Maalem to take part in his Rites of Spring, a West African 
production on Stravinsky's score. Nevertheless she continued to work with the Senegalese company in-between much better paid tours abroad.

Among this generation, Landing Mané was 'freelancing' when he joined the company in the mid-1990s. He had acquired experience in a wide range of genres by virtue of his membership of neo-traditional troupe Bakalama since childhood, where he tried his hand at choreography and drama, and his participation in Cissé's Sotiba Boys and the Manhattan Dance School. His practice of Cuban dances and American 'street dances' during weekly evening dances in his Dakarois neighbourhood in the 1980 s also fed into his early choreographic work. Mané was eventually recruited by British Candoco Dance Company to come to London in the late 1990s, where he gradually established himself as a successful teacher of West African drumming and dancing. Meanwhile, he continued to work with younger Bakalama performers during visits to Senegal.

As these examples show, the generation of the 'state's orphans' struggled with the fact that political patronage of the arts was on its last leg when they came of age. The search for innovation now existed side by side with a re-enchantment with 'traditional' performing practices. It is thus common to hear artists from this generation claim the moral high ground by framing their choreographic production as social commentary. By so doing they align themselves with griots and other specialized performers in the region, whose art, they argue, was at its best when it commented critically on social ills. But such arguments are also thinly veiled critiques of the adjacent generations' alleged lack of morality: the seniors are charged with 'selling out' to the state to promote their own careers and with little regard for those coming after them, while the juniors stand accused of losing their morality in their 'rush' to succeed. Indeed being 'in a rush', in Wolof-speaking Senegal, is seen as synonymous with being devoid of morality, as not being able to wait for one's destiny to be realized in the proper order of things (Sylla 1994).

Nevertheless, the 'state's orphans' deployed similar strategies to the previous generation in their attempt to acquire new choreographic skills so as to be freer to move across space and social spheres. Without the support of the Senegalese state and with the increasing difficulty to travel to European countries however, the social spheres they were able to engage with either shrank back to a regional level, or became cut off from Senegal altogether when individuals made their way into the world individually. Amidst this movement inwards, new, fleeting spaces were emerging: those created by short-term 
workshops held in various parts of Africa, Europe and North America. These new modes of engagement with global circuits were going to be one of the defining characteristics of the next generation, the 'soloists'.

\section{The third generation: the 'soloists'}

With the third generation, whom I call the 'soloists', individual agency in choreographic work came to the fore very strongly. They have mainly become active in the second part of the 1990 s and in the 2000s, though some were in fact trained much earlier. Working more than ever with an eye to the wider world, the 'soloists' distinguish themselves through their confidence in their capacity to contribute to global artistic circuits in major ways. New performing skills are increasingly conceived of in terms of acquiring 'life skills', and choreographic collaborations with artists from other parts of the world have become sought after, not only as a way of achieving a mobile lifestyle but also more egalitarian relationships with other parts of the world. The social space they create through their engagement with multiple performing genres, technologies and types of events still has West African urban fields at its core, but it is more fleeting and rapidly shifting than ever before. Importantly, too, it now includes a virtual dimension through the use of the internet to engage with global artistic networks.

Thus on the evening of the $9^{\text {th }}$ of July 2009 , an intriguing spectacle took place in the arts gallery at the French Institute in Dakar. Four male and four female dancers performed moves on the theme of 'the birth of movement'. ${ }^{8}$ This was the opening of a photographic exhibition entitled Danser L'espoir ('Dancing Hope') by two well-known photographers in the field: Antoine Tempé and Elise Fitte-Duval. Three of the dancers had taken part in workshops at Germaine Acogny's Ecole des Sables, and the performance had been put together by Fitte-Duval along with Congolese dancer-choreographer Andreya Ouamba. Ouamba and Fatou Cissé, daughter of Ousmane Noël Cissé, form the core of a successful contemporary dance company established by Ouamba in the early 2000s: Premier Temps ('First Count'). There was striking similarity between the poses captured on some of the photographs and the poses the dancers occasionally froze into. This was a highly

\footnotetext{
8 There are extracts of the performance on youtube; see, for example 'Andréya Ouamba Cie 1er Temps Performance Photo Danse Elise \& Antoine’ at http://www.youtube.com/watch?v=5SURCn2Rqs8 (accessed $19^{\text {th }}$ April 2012).
} 
individualized performance style, with a keen consciousness of the layers of visual media involved: the still photographs, the images of dancers being photographed and projected simultaneously as they performed, and the visual impressions created by the space itself. This illustrates one of the characteristics of the 'soloists' generation: movement is always produced with images in mind, either from photographs or from TV, dance films, music videos, and increasingly, the internet. This is a generation which has reached 'artistic adulthood' just as all these media became widely available in urban Senegal, and which has developed a reflexive, intimate relationship with images.

Why characterize this generation as 'soloists'? Although solo dancing is not new in the region, it has become more prominent in the past decade. Similar developments have taken place elsewhere in Africa, where artists have influenced each other through the circulation of dance images and pan-African tours (often organised and supported by the network of French cultural centres), international training workshops in the continent's emerging choreographic centres. Thus one of the first creations by third-generation choreographer Djibril Diallo was Os Sacré ('Sacred Bone'), a solo presented at the French Institute in 2003. A former university student in philosophy, Diallo was involved in youth theatre when he was recruited by Mrs Acogny to take part in one of her workshops. The touring experience with the Coq Est Mort production gave him the confidence to set up his own company in 2001, Kakat'Art. Though the group is no longer active, the 2003 solo remains what Dakarois dance people remember most vividly from Diallo's prolific work between 2001 and 2006. In 2003, choreographer, Kaay Fecc ${ }^{9}$ festival organizer Gacirah Diagne re-staged Picc mi ('The Bird' in Wolof), a solo she had created for herself when dancing with New York-based Urban Bush Women a few years earlier. This time the dancer was Fatou Cissé, and after several performances at various venues in Dakar, the solo toured French Cultural Centres in several African countries. Since then, Cissé has choreographed her own solos, most notably Regarde Moi Encore ('Look at me again'), which she performed at several French Institutes across Africa in 2012. Since 2008, an annual festival of duets and solos has even developed very successfully in Senegal's former colonial capital, Saint-Louis.

Although this represents a further step in the individualization of creative agency already discernible with the 'state's orphans', this does not mean that the performers have

\footnotetext{
${ }^{9}$ Kaay Fecc is both a professional dance association and a biennial dance festival held in Dakar. It was set up in 2001 to promote dance and offer workshop-based training in a wide variety of genres.
} 
become exclusively concerned with their autonomous selves. Rather, the current interest in solo work has been very much shaped by the structure of international funding. In the nearabsence of state funding, choreographic production in Africa has become heavily dependent on international funding agencies, and French state agencies in particular (see Sieveking, this volume). These agencies, in particular the French Institute, ${ }^{10}$ have come to form an important aspect of French foreign policy in Africa since the early 1990s. Thus it is the French Institute that is behind the most pan-African choreographic biennale, Danse l'Afrique Danse (formerly Rencontres Chorégraphiques de l'Afrique et de l'Océan Indien). The French Institute also has an important 'prescriptive power' with other European funding agencies, both national and multilateral, who often consult its experienced officers to identify up-andcoming African artists. This becomes visible when artists whose relationships with the French Institute have soured suddenly find it difficult to get funding elsewhere. In short, the French Institute sets the tone of contemporary choreographic production across Africa. In Senegal, it is not too far-fetched to say that it has replaced the nationalist-period state as the main patron of the arts. It was therefore significant that the African biennale introduced a solo category when it was held in Tunis in 2008. There was recognition that young choreographers across the continent were doing solo work that was worth marketing, but there was also the fact that solos are cheaper to stage, and therefore easier to promote for touring. The performers themselves often value the autonomy and the higher fees that come with solo work. They feel less dependent on collaboration problems with fellow dancers changing plans at the last minute or running away during tours, not to mention the difficulty of obtaining group visas.

The decline in state-funded training institutions has also contributed to the individualization of choreographic creation because it has become difficult for performers to find spaces big enough for groups to work on a regular basis. People now rely on occasional workshops, and multiply short-term training in a variety of genres. Short-term training has reinforced the sense that speed is of the essence, and that one no longer needs to wait for years to become a successful artist. Workshops have become 'fast-track' routes at several levels: they are training opportunities in new choreographic techniques, but also opportunities to meet artists from other parts of the world who have come to West Africa in

\footnotetext{
10 The structure and name of the main French funding agency for the arts in Africa has changed several times in the past decade, from AFAA (Agence Française d'Action Artistique), to Cultures France, and since 2011, L'Institut Français.
} 
search of inspiration for their own work. Collaborative choreography has thus boomed with this generation, and the impetus has come from local performers as well as visiting artists. Younger dancers know that they must show some proficiency with choreographic creation in order to work with visitors. Fast-track training in choreographic techniques also became popular as Senegalese performers realised that this might increase their chances of being recruited for international productions. Heddy Maalem's recruitment of West African dancers for several of his creations since 2000 has had a significant impact in this respect. The auditions he held in various West African cities came in the wake of an earlier production by French choreographer Mathilde Monnier, whose show Pour Antigone toured for several years following her recruitment of dancers in Burkina Faso in 1992. Many of the 'soloists', however, continue to engage with neo-traditional dance troupes working according to more hierarchical apprenticeship methods, where they enjoy strengthening their skills in West African performing styles as well as the sense of belonging to a kind of surrogate family.

The 'soloists' have also benefitted from the effervescence generated by the arrival of artists from other African countries in the 2000s. Ouamba, for example, was one of several Congolese dancers who came from Brazzaville in the early 2000s. Like many dancers of his generation, as a teenager in Brazzaville in the late 1980s - early 1990s he had been a fan of American 'street' dances. In the 1990s he had joined a dance troupe recently established by Chrisogone Diangouaya, a dancer then known as the 'Michael Jackson of Brazzaville'. Many boys looked up to him as he performed American songs with a near perfect American accent. Even though Ouamba did not speak English at the time, the songs and the dances had nurtured his desire to become part of a cosmopolitan artistic community. Meanwhile Diangouaya had realised that in order to be invited to perform abroad, his troupe had to offer an 'African' programme. He learned some of the region's dances to supplement the ones he already knew from his father, and taught them to his dancers. In 1999, having attended one of the Ecole des Sables's early workshops, Diangouaya was recruited for the Coq est Mort project. Ouamba followed in his footsteps, and given the dramatic insecurity that was reigning in Brazzaville then, he decided to stay in Dakar. He has since established himself as a successful choreographer alongside partner Fatou Cissé, and runs his own series of contemporary choreographic workshops with the support of the French Institute and visiting dancer-choreographers from a variety of countries in Africa and Europe. 
Like the previous generation, the 'soloists' are concerned with critical social commentary, but they often draw much more explicitly on their personal experience. A case in point is a piece by Senegalese dancer Pape Ibrahima Ndiaye (a.k.a. Kaolack), for which he won the first solo prize at the 2008 'Rencontres' in Tunis. After a spell with a youth contemporary company led by $5^{\mathrm{e}}$ Dimension performer Papa Sy, Kaolack took part in several workshops with Kaay Fecc and at the Ecole des Sables, and worked with Germaine Acogny's Jant bi Company. His 2008 solo, J'accuse, was inspired by a traumatic experience of racism and detention in a North African country. The anger he retained from the incident fed into the forceful movement texture which has now become his trademark. The piece featured, for example, at London's Dance Umbrella festival in 2009:

'J'Accuse, Danse L'Afrique Danse prize-winner (2008), is a physically and emotionally charged solo which asks important questions about the condition of the African person in a global context. Based on personal experiences of prejudice, travel restrictions and ignorance, Kaolack has created a polemical response which celebrates an African identity and confident stance in the face of an unfair world.' (Dance Umbrella 2009)

Dancer-choreographers of the third generation are thus increasingly confident about their artistic abilities, and about their engagement with social spheres far beyond the Francophone world.

'Contemporary' choreographic work, therefore, reflects and shapes new notions of the person in Dakar, a process which mirrors similar developments in other African cities: social spaces are created in which persons are capable of autonomous action, yet also tied to families (real or surrogate). Though persons in Wolof-speaking Senegal were always understood as shaped by a combination of both dimensions, autonomy was not valued in young people before they had proved themselves to be capable of enduring the obstacles of life with dignity (Sylla 1994). The latest generation of dancer-choreographers embody a change in this lengthy process, not only by being confident about showing their work in public at an early stage in their training, but also because their families and peers increasingly value their individual achievements.

In terms of spatial practice, what characterizes this 'third' generation is a renewed engagement with global artistic circuits, in more fleeting ways than the 'first' generation but 
with fresh aspirations to transform Africa as a place-in-the-world. Furthermore the social spaces now created through workshop practice, participation in transnational choreographic events and a continued engagement with different genres also integrate networks of images and virtual communication as an integral component, which increases the fleeting, shapeshifting character of spatial choreographic practice. The urban context is crucial in this respect since performers who do not live in one of the major Senegalese cities have far fewer opportunities to circulate images of their work over the internet, and to establish worldwide networks.

\section{Performance, Africa's place in the world and the art of life in urban Senegal}

In this article, I have suggested that looking at the engagement of individuals with different performing genres and social spheres over time illuminates the ways in which urban social spaces in Africa are constituted in connection to other parts of the world. It is not just that individuals move between urban Africa and places outside the continent, it is also that this movement is socially meaningful in a multitude of ways. The travelling lifestyles performers establish are thus conceived as being in continuity with older modes of spatial mobility in the Senegambian region, where travel was seen as essential to the acquisition of specific skills and the achievement of social adulthood.

One important aspect of spatial and social mobility which I have only dealt with implicitly in this article, is the issue of power. It is inherent in both Lefebvre's (1974) and Massey's (1991)'s treatment of 'space' as produced by historical processes and human interaction, and it is important to reflect on this in summarizing the main points developed in this article. Indeed, what is significant in the forms of mobility described here is that they are produced by people's aspirations to social mobility and innovation on the one hand, and by the agency of states and global funding structures on the other hand. This is why the urban context is highly significant in this mobility: in coastal West Africa, cities have grown out of a joint history of violence and trade, first with the transatlantic slave trade and later with colonialism. Urban fields were produced by a history of global capitalist expansion which found its lifeblood in the subjugation of Africans and their resources. Aspirations by the younger Senegalese (and other West African) performers to use these historical spaces, connections and even modes of creation to challenge Africa's place in global arts world can 
therefore be seen as a powerful political gesture. The engagement of young African choreographers with contemporary dance so as to take part in workshops and produce choreographic work with dancers from anywhere in the world, for example, is an embodied attempt to challenge structures of domination, both in terms of Africa's place in the world and in terms of internal social hierarchies. In his brilliant essay on the post-colonial condition in Africa, Mbembe (2001: 4) reminds us that too often, Africa 'stands out as the supreme receptacle of the West's obsession with, and circular discourse about, the facts of "absence," "lack," and "non-being"'. What young dancer-choreographers from Senegal and other parts of urban Africa are trying to do, it seems, is to use the act of performing, and the performing skills they know to be valued as part of the global imagination about Africa, to replace this absence with an embodied presence.

At the level of everyday life in urban Senegal, the search for new skills and the to-and-fro movement between different genres of performance appear as a dynamic process which drives a simultaneous engagement with different social spheres, not only within the region but also outside the continent. This is the kind of strategy Simone (1998) suggests has become essential to 'making it' in African cities, and although flexibility and multiple engagement with social spaces near and far constitute an enduring aspect of social life throughout West Africa, there are now few other alternatives to achieve a 'good life'. For young city dwellers, it has become urgent to develop a wide repertoire of skills rather than wait for years to become highly specialized in a single genre. A simultaneous engagement with different genres also enables individuals to maintain relations of dependency in some contexts while being more autonomous in others, thereby bypassing older hierarchies of experience. This is just what the third generation 'soloists' do when they create their own pieces for the African biennale while also performing with a neo-traditional dance troupe, and joining in popular dance events in their neighbourhood. Performing skills, in contemporary African cities, thus become 'life skills'.

\section{References cited}

Abbink, Jon , and Ineke Van Kessel. 2005. Vanguards or Vandals: Youth Politics and Conflict in Africa. Leiden: Brill. 
Benga, Adrien Ndiouga. 2002. "Dakar et ses tempos: Significations et enjeux de la musique urbaine moderne (c.1960-années 1990." In Le Sénégal Contemporain, edited by Momar C. Diop. Paris: Karthala. Original edition

Carling, Jørgen. 2002. "Migration in the age of involuntary immobility: Theoretical reflections and Cape Verdean experiences." Journal of Ethnic and Migration Studies 28 (1):5-42.

Castaldi, Francesca. 2006. Choreographies of African Identities: Négritude, Dance, and the National Ballet of Senegal. Urbana: University of Illinois Press

Christiansen, Catrine, Mats Utas, and Henrik E. Vigh. 2006. Navigating Youth, Generating Adulthood: Social Becoming in an African Context. Stockholm: Elanders Gotab AB.

Dance Umbrella. 2009. A brief encounter with... Kaolack (Senegal) - J'Accuse. $<$ http://www.danceumbrella.co.uk/page/3113/JACCUSE/110\%3E.

Diop, Abdoulaye-Bara 1981. La Société Wolof : Systèmes d'Inégalité et de Domination. Paris: Karthala

Drewal, Margaret T. . 1991. "The state of research on performance in Africa." African Studies Review 34 (3):1-64.

Durham, Deborah. 2000. "Youth and the social imagination in Africa: Introduction to Parts 1 and 2." Anthropological Quarterly 73 (3):113-120.

Gore, Georgiana. 2001. "Present texts, past voices: the formation of contemporary representations of West African dances." Yearbook for Traditional Music 33:29-36.

Hale, Thomas 1999. Griots and Griottes. Bloomington: Indiana University Press

Harney, Elizabeth. 1996. "'Les chers enfants' sans papa." Oxford Art Journal 19 (1):42-52.

Harney, Elizabeth 2004. In Senghor's Shadow: Art, Politics and the Avant-Garde in Senegal, 1960-1995. Durham: Duke University Press

Honwana, Alcinda, and Filip De Boeck. 2005. Makers and Breakers: Children and Youth in Postcolonial Africa. Oxford: James Currey.

Irvine, Judith T. . 1989. "When talk isn't cheap: language and political economy." American Ethnologist 16 (2):248-267.

Jonsson, Gunvor 2011. Non-migrant, sedentary, immobile, or "left behind"? Reflections on the absence of migration. IMI working paper no.39, http://www.imi.ox.ac.uk/pdfs/imi-working-papers.

Lefebvre, Henri. 1974. La production de l'espace. Paris: Anthropos

Massey, Doreen B. 1991. "A global sense of place." Marxism Today:24-29.

Massey, Doreen B. . 1994. Space, place and gender. Cambridge: Polity Press

Mbembe, Achille 2001. On the Postcolony. Berkeley: University of California Press

Neveu Kringelbach, Hélène. 2013. Dance Circles: Movement, Morality and Self-Fashioning in Urban Senegal. Oxford: Berghahn Books

Reynolds Whyte, Susan, Erdmute Alber, and Sjaak Van der Geest. 2008. "Generational connections and conflicts in Africa: an introduction." In Generations in Africa, edited by Erdmute Alber, Sjaak Van der Geest and Susan Reynolds Whyte. Berlin: LIT Verlag. Original edition

Schumann, A. (2012): A generation of orphans: the socio-economic crisis in Côte d'Ivoire as seen through popular music. In: Africa, 82, 4, p. 535-555

Simone, AbduMaliq. 1998. "Urban social fields in Africa." Social Text 56:71-89.

Snipe, Tracy D. 1998. Arts and Politics in Senegal 1960-1996. Trenton: Africa World Press

Sylla, Assane. 1994. La Philosophie Morale des Wolof. 2nd ed. Dakar: IFAN. Original edition, 1978. Reprint, 1994 
Tamari, Tal. 1997. Les Castes de l'Afrique Occidentale. Nanterre: Société d'Ethnologie Vigh, Henrik E. . 2006. Navigating Terrains of War: Youth and Soldiering in Guinea Bissau. Oxford: Berghahn Books

Weiss, Brad. 2009. Street Dreams and Hip Hop Barbershops: Global Fantasy in Urban Tanzania. Bloomington: Indiana University Press

White, Bob W. 2002. "Congolese rumba and other cosmopolitanisms." Cahiers d'Etudes Africaines 42 (168):663-686.

Wright, Bonnie. 1989. "The power of articulation." In Creativity of Power: Cosmology and Action in African Societies, edited by W. Arens and Ivan Karp, 39-57. Washington: Smithsonian Institution Press. Original edition

Wulff, Helena. 1998. Ballet across Borders: Career and Culture in the World of Dancers. Oxford: Berg 